\title{
In the New Institutional Economics Approach R. Coase and Law, D. North and Social Psychology Context: Pluralist Approach Opportunities in Economics
}

Selma Sevinç ORHAN, Department of Economics, Faculty of Economics and Administrative Sciences, Pamukkale University, Turkey; e-mail: sorhan@pau.edu.tr

\section{Yeni Kurumsal İktisat Tarihi Yaklaşımında R.Coase ve Hukuk, D. North ve Sosyal Psikoloji Bağlamı: Ekonomide Çoğulcu Yaklaşım Fırsatları}

\begin{abstract}
In this study the relation between the OIE and the NIE (New Institutional Economics) approach is analyzed. In this way, the emphasis is on the main contrasting points of both approaches to mainstream economics. The institutions are as stated by both the precursors of the OIE and NIE approaches, Veblen, Commons, Coase and North analyzed as thinking habits, as behavior constraints in the social rules, as the legal context of the liberal theory. OIE and the NIE approaches demonstrate continuity through ontological point of view towards the concept of institution. Despite theoretical and methodological differences between them, due to the continuity relationship, the NIE plays a carrier role in transferring heterodox terms to mainstream economics. The continuity relation provided by institutions strengthens the pluralist methodology in the economy.
\end{abstract}

Keywords

New Institutional Economics, Original Institutional Economics, Coase Theory, History of New Institutional Economics, Pluralist Methodology in Economics.

JEL Classification Codes : $\quad$ B25, B52, D23.

Öz

Bu çalışmada, OKİ (Orjinal Kurumsal İktisat) ve YKİ (Yeni Kurumsal İktisat) yaklaşımları arasındaki ilişki analiz edilmektedir. $\mathrm{Bu}$ yolla, her iki yaklaşımın yerleşik iktisat karşısındaki konumu ortaya konulmaktadır. OIE ve NIE yaklaşımının öncüllerinden Veblen, Commans, Coase ve North tarafından belirtildiği gibi kurumlar, formalizm dışında bir yöntemle, düşünme alışkanlıkları, sosyal kurallarda davranışsal kısıtlar, liberal kuramın yasal bağlamı olarak analiz edilmektedir. OIE ve NIE yaklaşımları, kurum kavramı konusunda, ontolojik yönden süreklilik göstermektedir. Aralarındaki kuramsal ve metodolojik farklılıklara rağmen, bu süreklilik ilişkisi yoluyla, NIE yaklaşımı belli heterodoks kavramların yerleşik iktisada aktarılmasında taşıyıcı bir rol üstlenir. Kurumlar yoluyla sağlanan süreklilik ilişkisi, ekonomide çoğulcu metodolojiyi güçlendirir.

Anahtar Sözcükler : Yeni Kurumsal İktisat, Orijinal Kurumsal İktisat, Coase Kuram1, Yeni Kurumsal İktisat Tarihi, Ekonomide Çoğulcu Yöntem. 
Orhan, S.S. (2016), "In the New Institutional Economics Approach R. Coase and Law, D. North and Social Psychology Context: Pluralist Approach Opportunities in Economics", Sosyoekonomi, Vol. 24(28), 189-208.

\section{OIE and NIE Approaches in the Face of Mainstream Economics}

Original Institutional Economics (OIE) approach launches evolutionary change debate through institutions against the metaphors of the classical economics and neoclassicism such as invisible hand, natural order and clearing market. In his concept of institutions, T. Veblen emphasizes the necessity of evolutionary change of the economic theory as a social institution and a scientific discourse, while J.R. Commons identifies the legal principals as the agenda of economics which protect individual motifs and determine the terms of the social contract and public behavior rules. Both predecessors of the OIE approach maintain a heterodox stance covering the methodological holism against the formalist methodological individualism approach of Neoclassicism. The OIE is a dissent approach in the heterodox wing against both the invisible hand metaphor of classics and the clear market approach of neoclassicism which is demoted to methodological individualist marginalist maximization principle.

The OIE approach does not reject the market ideology owned by the mainstream economics. The social context of human and economics is discussed within the framework of law with a liberal spirit by Veblen and Commons. The development course of economic theory and economic system takes the place of the natural order metaphor within the evolutionary change line. While maintaining a rather stiff oppositional stance in the face of mainstream economics, the OIE approach does not move away from the liberal philosophy which constitutes the essence of the market economy. The OIE approach is in the opposite of formalist method of neoclassical marginalist price theory of the mainstream economics. However, the OIE approach cannot develop a new theory in the face of marginalist price theory fed with the liberal spirit.

The meeting of economics with the institutional terminology begins with the OIE. Corresponding to the marginalist methodological content of the neoclassical approach the OIE with evolutionary process approach (context) carries the institutional aspect of the market economy to economy economic science. In this way, the OIE criticizes both the classic institutionalists' the natural order/the invisible hand metaphor and the abstract deductive methodology of neoclassic institutionalists. As stated by the founder of institutional approach Veblen, mainstream economics is a static science that does analysis by Classic and Marginal paradigms.

It is the approach built around "pioneer institutionalists" such as T. Veblen and C. Ayres, J.R. Commons, The Old Institutional Economics institutionalists in the economics literature called by Hamilton, and in contemporary economics literature further developed by G. Hodgson, W. Samuels and M. Rutherford. The rational economic behavior abstracted from all times and places in mainstream economics turns into economic behavior shaped by the institutional and cultural contexts in the OIE approach. According to modern representatives of the OIE approach such as J.K. Galbraith (1967), M. Rutherford (1995) and Hodgson (1998) Institutions and institutional development process in social life is discussed again in the context of economics, politics and social psychology within the 
themes of group behavior, perception of identity, social status, ideology, power relationships.

In compliance with the OIE approach, classical and neoclassical economics' idealized perception of the world, which is fictionalized by deduction, is far from theoretical and methodological aspects of the evolutionary approach. The OIE is out of scientific research program that is based on the method of mainstream economics and marginal price theory. The basic argument of the OIE approach is institutionalism. Economic science is historical and cultural one. Based on Parada (2001: 59), institutional economics tries to solve the problems of life with a paradigm movement alternative to the mainstream theory. The conduct motivation of economic agents "personal interest" which is counted as external, cannot be fit into the principle of profit maximization. Economic motivation of people is being shaped as "the perception of self-interest" as a result of inner institutional-historical process.

As stated by Parada $(2001,59)$, the paradigm of the OIE approach:

1. Economics analysis is a dynamic process. It is based on evolutionary processes described in Dewey's evolutionary means-result relationship.

2. Allocation of goods and services are realized in harmonics order through "invisible hand". Resource allocation process is shaped in changing cultural environment according to the technological requirements.

3. Resource allocation problem is not only a process provided by the market, it is executed by the interactive values system within power/government and values system.

4. The distribution of the decision-making process does not work according to "one dollar equals one vote" principle, but it develops depending on the government and wealth relationship.

5. Technological change and consumer freedom is limited by the concentrated force. Decision making process does not occur in full competitive market structures. It is based on the view of involvement in economic process.

Moreover, Langlois (1986), in "Economics as a Process" symposium, described the NIE as a mix of nine different theories under the "Modern New Institutional Economics Approach" title. In accordance with it, these are the most mentioned approaches: Property Rights Approach, Economic Contract Theory, Transaction Cost Approach and New Institutional Approach to Economic Theory. In addition, Constitutional Choice Theory, Collective Action Theory, Public Choice Theory, Evolutionary Economics Theory and Modern Austrian Economics Theory are collected under the NIE title.

New Institutional Economics was firstly used by O. Williamson in the content covering economics of property rights, work economics, comparative systems, the 
organization theory and microeconomic theory (Richter, 2000: 11-24). On the other hand, Coase in his works does not use the definition of new institutional economics, instead he prefer the concept of the modern institutional economy. Richter states that because of its wide range, the NIE literature is collected within the four main schools: Property Rights Economics (PR) (Coase, Alchian), Transaction Costs Economics (TC) (Coase, Williamson), Contract Economics Theory (CE) (Spencer, Mirrless, Stiglitz, Williamson, and Macneil), and History of New Institutional Economics Approach (NIEH) (D. North).

The OIE and NIE approaches are beyond the classical and neoclassical paradigm. In contrast to different missions within both approaches, the concept of institutions shows continuity in content. Both approaches have similarities on the concept of institution from an ontological point of view. The institutions are as stated by both the precursors of the OIE approach Veblen and Commons and the founder of NIE approach R.Coase, D. North and O. Williamson: analyzed as thinking habits; as behavior constraints in the social rules; as the social, cultural, and legal context of the liberal theory and as an evolutionary element of social change through a method outside the formalism.

\subsection{Habits of Thinking as Institutions}

The opinion given in the process of social change by institutions towards behavior is the starting point of evolutionary change approach. As per T. Veblen, institutions are the habits of thinking that are commonly associated with certain functions of the individuals and society (Veblen, $1898 \mathrm{a} ; 1898 \mathrm{~b}$ ). As to the OIE approach, through changing the habits of thinking of the individuals by choosing better leads to institutional change. From the economic point of view, social evolutionary process is fed by the clashes between ritual and financial attitudes of social forces engaged in the industrial activities and of the leisure class. (Parada, 2001: 49-50).

In reference to the evolutionary process approach of Veblen, Classic paradigms' "hedonic type of person" cannot be reconciled with the real life human behavior (Veblen, 1898 to 405-411). In Veblen, marginalists' profit maximization approach could not go beyond being just "enlightening calculator" in economics. Based on institutionalist approach, Grunch believes that (1947) the world is not formalist as foreseen in mainstream economics; rather the real world is culturalist. Economics science requires neither the assumption of rational behavior nor equilibrium approach. The process is important in economic analysis. Economics is projection of history and cultural process. Unlike the classical and marginalist approach, the OIE follows a historic methodology comparative with information gathered from anthropology.

The OIE tries to choose the one closest to the truth among facts and alternatives. By the influence of German Historical School T. Veblen makes analysis through inductive 
methodology ${ }^{1}$. The institutional approach of the OIE is fed from Dewey's pragmatism and instrumentalism ${ }^{2}$. Rutherford asserts that (1994) there are methodological differences between the OIE and the NIE such as rationality/bounded rationality, formalism/antiformalism, methodological individualism/holism and inductive/deductive reasoning. Unlike mainstream paradigm, in the NIE, individuals make bounded rational choices due to the limited information equipment. The markets institutionalized through property rights and contract economies minimize transaction costs which were created by bounded rational behavior in the limited information environment.

Similarly, according to NIEH approach, D. North defines institutions as habits of thinking of the individual and habitual mainstream behavior patterns of social life (North, 1990: 3). Based on both approaches institutions determine individual behavior as the habit of thinking. However, the social context by Coase and North introduced into mainstream theory through the concept of institution is a part of Neoclassicism's event - based Marginalist approach. Since the NIE approach tries to price the public goods that cannot be priced by marginalism within the market rules. It is set in the hard core of Neoclassicism mainstream economics approach. Yet, like the OIE approach, it criticizes formalist methods of mainstream economics. In the OIE approach, with the concept of institutions, Commons and Veblen are against the abstractive analysis and all reductionist method of marginalist methodology of the neoclassical economics.

In the NIE approach, the meaning of the concept of institution given by North and Williamson is similar to the perspective put forward by Veblen and Commons. Still, the mission of the concept of institution is different in the NIE approach from the OIE approach. In North's approach, institutions seen as part of a social context of the human, in time move away from the context of methodological individualism of neoclassical formalism. Institutions open the door slightly to a holistic method by trading places with the concepts developed by social psychology as social cognition, social representations, mental models and social learning. In North's recent studies, there's a share of relationship established between economics and anthropology as much as the relationship between the economic and social of psychology behind the holism orientation methodology.

I As to Veblen, in the approach of Schomoller, the representative of the German Historical School, continuity of institutional change and development is evolutionary. Schomoller is more Darwinian than Hegel (Veblen, $1898 b, 4)$.

2 Dewey's concept of inquiry make an uncertain situation certain and means to manage and organize. It is a process that foresees the development of the meaning and the source of the problem in the face of uncertain situations and causality relationship within a common understanding. In fact, the concept of inquiry takes us to deductive and inductive argument. 
Orhan, S.S. (2016), "In the New Institutional Economics Approach R. Coase and Law, D. North and Social Psychology Context: Pluralist Approach Opportunities in Economics", Sosyoekonomi, Vol. 24(28), 189-208.

\subsection{Behavior Constraint in Social Rules as Institutions}

The idea that the institutions restrict the behavior in the social life as the system of rules is the dates back to Commons. This approach covering the limit of coercion in social life and negotiation processes (bargaining) is the basic argument of liberal theory where economic and political power is questioned. Based on Commons, institutions build the rules of social life by supervising the collective action while expanding the boundaries of individual action. On the other hand, contracts regulating economic activity in the market economy, and appraisal rules (bargaining, managerial and rationing) measuring performance of the firms are indispensable economic institutions of a liberal economics. In liberal economics institutions are set of social structure transforming rules that limit the power of the state and individual over other individuals.

The concept of institution according to architect of NIEH approach - D. North is similar to Commons' functionalist institutionalism approach that regulates the economic life. The OIE institutional environment refers to background "constraints" of economic action and "rules" of the competitive team game that shapes the behavior. Unlike in the OIE approach, institutional environment is more comprehensive rules of the game in the NIEH approach. In the market game institutions are regulated by both formal explicit rules such as constitutional arrangements, laws and regulations, property rights and informal implicit rules social customs and norms.

North's concept of institution which is considered as an element of stability in society is moving away from the assumptions of mainstream theory and coming closer to Commons' heterodox institution concept that limits and controls the pressure. North describes formal constraints economy, political and legal rules and agreements. From functionalist point of view, institutions are behavioral constraints reducing transaction costs and facilitating the change. In social life institutions refer to, on the one hand, the process of building constraints that shape the individual, on the other hand, they refer to the social context in which the constraint are built. In this way, while discussing the constraints on individual and social behavior in the context of institution concept, on the other hand, the process that built the social area is being discussed.

From this aspect, discussions of institutionalization extend to social psychology, sociology and liberal theory. O. Williamson classifies the level of institutionalization similar to the stages of liberal society foreseen by Commons. As for Commons contract making, the regulation of evaluation operations of administrative structures and economic activities, institutional constraints regulating power relations are called as the building process of the positive political theory and the governance structure in Williamson's transaction cost approach (1975). Both Williamson's and Commons' institutions are similar in terms of the function of shaping individual behavior. According to Williamson, the development of both self-consciousness in social life and citizenship awareness in the public sphere depends on motivation channel of human as well as the change performance of economic and political institutions in society. The change performance of economic and political institutions as 
Orhan, S.S. (2016), "In the New Institutional Economics Approach R. Coase and Law, D. North and Social

Psychology Context: Pluralist Approach Opportunities in Economics”, Sosyoekonomi, Vol. 24(28), 189-208.

much dependable as informal rules on the implementation and change performance of formal rules which are achieved by building positive political theory and allocation of property rights. According to Williamson, construction phase of governance structure in parliamentary systems ends with the stage providing the effectiveness of resource allocation (Williamson, 2000: 597-599).

\subsection{Institutions as Evolutionary Role in Social Change}

According to New Institutional Economics History approach, institutions in social life transfer social representations between generations through cognitive models (Orhan, 2015). For thousands of years institutional environment has been shaped in accordance to experiences and perceptions which were produced in cognitive models and transferred between generations. The ongoing debates on institutional context in economy are reflections of social learning process in economic science. During the diffusion process of economic and political power built-in values of the system, perceptions and experiences are transmitted through social learning (North, 1978, Denzau \& North, 1994). All these perceptions, experiences, informal and formal rules transferred through social learning form the institutional environment.

North gives emphasis on relationship of culture and institutional environment in the process of institutional change. Ayres's OIE approach institutional structure shows similarity with the content imposed on culture. (Parada, 2002: 50). Support provided by the public during the institutional change process increases the development performance of the economy. Although the OIE and the NIE approaches have similarities on the concept of institution from ontological point of view, they differ from each other in terms of analysis methods due to paradigm differences. The evolutionary change and building process institutions of social life in modern economics literature shapes the institutional development and development literature in the context of institutional performance. However, while the OIE approach is located outside the mainstream economics paradigm of the NIE approach, the NIE approach makes analysis based activities the mainstream economics paradigm.

As per D. North's New Institutional Economics History approach, the development performance of the economies depends on the institutional change capacity of the economy. In public institutions, the bureaucratic operations and relationships of interests are institutionalized by being discussed in the context of Property Right. Institutions in Economics require a combined discussions of the economic and political decision- making mechanisms such as the allocation of property rights, regulation and implementation of tax legislation. In a sense, institutional structure of the economy is shaped in descending order by political institutions. Here the institutions are taken as constraints, so this way complementary relationship between institutions and individual preferences is highlighted. Whereas, in contemporary OIE literature, G. Hodgson, W. Samuels, D. and M. Rutherford discuss the economic behavior of individual, who is considered as a rational actor of orthodox economics, in the context of institutional culture. As to J. K. Galbraith (1967), Rutherford (1995) and Hodgson (1998) group behavior, sense of identity, social status, 
Orhan, S.S. (2016), "In the New Institutional Economics Approach R. Coase and Law, D. North and Social

Psychology Context: Pluralist Approach Opportunities in Economics", Sosyoekonomi, Vol. 24(28), 189-208.

ideology and power relations are the primary determinants of institutional change in economic life.

Per North and Richter, institutional change performance is a part of the political process. North identifies "mental models", "ideology", "culture", "management structure" and "political institutions" as the dynamics of the institutional environment effecting the change. These dynamics are concepts, context and discourse of social sciences such as sociology, political science and psychology of partly heterodox world than the mainstream economics. Richter (2005, 11-24) considers that as components of institutional environment, norms, social customs, regulations and property rights and the historical performance of the economy determine the development story of the country. In fact, the development level of political institutions depends on the level of institutional performance. Richter $(2005 ; 2)$ thinks that there is a need for a new social theory including social sciences such as rapidly growing law, organization theory, political science, sociology and anthropology for the formation of economic, political and commercial institutions.

In North's approach, mental models developed through perceptual cognition are described in "Continuous cultural development" context reaching out to the concept of culture. Continuous cultural development is a prerequisite of Veblen's concept of evolutionary economics. Veblen states that economics is not the science of interests only. Economics, as a theory of cultural change, is an evolutionist science. Economics should be the science of the cumulative rankings of economic institutions. Evolutionist economics in Veblen's approach is a continuous cultural development. There are cumulative change performances of institutions and different economic interests among the dynamics affecting this development. Similarly, North believes that (1978, 1990); the basis of economic growth and development is the constant change of interests and institutions.

\section{R. Coase, O. Williamson and D. North in the NIE Approach}

The concept of institutions in NIE approach can be discussed in contexts such as social psychology, collective action, public choice theory, law and political economy. With its expanding content, the concept of institutions is making the modern economics a part of the social theory. In this section, the NIE approach is discussed in two axes. The first one: the approach of property rights, transaction costs and economies contract developed in the context of Coase and Williamson, the second one is NEIH approach developed by North method. Coase's analysis of property rights discusses the boundaries of all benefits and costs caused by organizations of firm scale in different sectors. In this way, market behaviors and relationships are institutionalized within the competition rules.

The allocation of property rights gives economic activity a legitimate content within legal contracts. Operating cost of the economy is reduced by pricing external costs and benefits of any kind of market among parties. According to Coase $(1937,1988)$ the institutionalization of market to the size of the firm provides optimal resource allocation by reducing the transaction costs of price mechanism. In a sense, Coase is a strong link between 
Orhan, S.S. (2016), "In the New Institutional Economics Approach R. Coase and Law, D. North and Social Psychology Context: Pluralist Approach Opportunities in Economics”, Sosyoekonomi, Vol. 24(28), 189-208.

economics and law. The relationship between economics and law set by Coase brings different constraint, which has not previously been in mainstream approach, into economic behavior in all economic systems, models and economic politics. This constraint, which has entered into behavioral functions of all market actors, especially firms being in the first place, creates a legal context of the market within the mainstream economics. The social context that has entered the economic theory with the legal concept in Coase's approach, it is the legal context of the state in liberal societies.

On the other hand, based on North's method and NIE approach institutions are the rules of the game which increase the developmental performance of economy. Formal and informal rules provide the institutional change process in market games and improve the performance of economy. According to North's approach institutions are the actors and rules of the game. Institutionalization process is provided by formal and informal rules consisting of culture affecting individual's market behavior, ideology, mental models and social representations, value systems, norms and laws. In this respect North stands at the crossroads between economics and social psychology, anthropology and political science.

As per North, institutions are in the role of political decision-maker mechanisms governing the process of change and regulating the rules of the game. In parliamentary systems, organizations / institutions are the processes that determine the actors of the game. The analysis of institutionalization is based on the building process of a market society, organizational behavior of market players, the institutionalization experience of individual and the learning processes. Law and economics relationship established by Coase's context of transaction costs and property rights is further expanded in the framework of economics, social psychology, management sciences and political science in North's context of institutional development performance. The allocation of property rights and contract economies, firm size organizations, formal and informal regulations consists of ideology, norms and laws are all defined as institutionalization within the contexts of Coase, Williamson and North. In both approaches, institutionalization targets efficiency in resource allocation by reducing the functioning cost of "price theory".

Efficiency in Coase's (1992) approach is based on the allocation process of property scaled at the firm level for institutionalization purpose within market relations such as change, production, management and finance. Efficiency in North's approach, brings up institutional change, regulation process and efficiency issues to the agenda of the economics literature by making the institutionalization process as the center of the market society. According to North's approach effectiveness analysis are the environments that affect institutionalization levels of society such as anthropology, history, identity, ideology, social psychology / social learning. According to this, the regulations providing institutional changes in economy must be in evolutionary process and in nature of improving development performance.

In Coase's approach, market relations are analyzed through the context of firmlevel organization moving from optimal price problem to property rights and contract 
economy. Coase's transaction costs, contractual economies, property rights and company analysis are outside the mainstream assumptions. This approach is beyond the mathematical context which uses the mainstream micro-analysis techniques. The reciprocal relationship between law and economics which ensured the competition in mainstream economics up until Coase (1960) is now ignored. How to build and sustain competition in markets? Which roles should companies take in the allocation process of resources? How will social benefits and costs be priced in market economy? There is not any response for these questions in mainstream literature. Spontaneity approach in market economy undertakes the law regulating role through the metaphor of the invisible hand.

North uses eclectic method in NIEH approach. On the one hand, market players are analyzed by behavioral aspects through procedural individualist methodology. On the other hand, the process of institutionalization in market societies is discussed through procedural holistic methodology. Institutionalization performance aiming at the optimal resource allocation coincides with optimization objective of the orthodox economics within both Coase's and North's approaches. NIE operates with within mainstream paradigm, but with a different terminology, context and methodology.

R. Coase discusses the legal aspects of competition in property rights and contract economies approach. In this way, the economy gets institutionalized in market scale primarily with help of the firm's institutional identity. In Coase's theory of price data considered property relations institutionalized through historical, cultural and legal process and transaction costs of reciprocal contracts between the parties are the efficiency objectives of mainstream theory. In one sense, it gains maneuver area for mainstream price theory. Coase doesn't part with the NIE approach from methodological point of view by adding the institutionalization process in competitive/noncompetitive markets through firms to marginalist approach. However, the market and competition is not a notion in Coase's approach.

Coase is distancing himself from market and competition perception which is regarded as a notion in an idealized world of economics. The market structure of mainstream economics is reduced to the concept of "firm" by Coase. Coase's firm/market distinction is totally different from both Walrasian (1834-1910) general equilibrium and Marshall's (1842-1924) partial equilibrium approaches of mainstream tradition. Prior to Coase theory, in the theory of imperfect competition there was not division of market and firm in: Dupuit's (1804-1866) theoretical framework emphasizing the concept of public interest and providing consumer surplus within public goods of the state; Cournot's (1801-1877) monopoly and duopoly market analysis; Chamberlin's (1899-1967) “The Theory of Monopolistic Competition" and kinked demand analysis, John Robinson's (1903-1983) marginal / average costs and the monopoly market analysis with income curve.

Effectiveness issue is discussed under four headings in Coase's approach: firstly, the property relations as a product of historical, social and cultural process yet accepted as data on price theory. Secondly, market relationships and pricing strategies functioning 
through reciprocal dialogue between the parties. On the other hand, contract economy and law covering price strategies, the problem of external costs and benefits in the context of market and law debate is carried out. Lastly, transaction costs arising from all market transactions. In mainstream economics the "efficiency" problem is discussed in the contexts of firm/market, individual/organization and institutional change within the approaches of Coase and North. In NIE, the presence of property rights and contract economies in firm size institutionalized markets lowers the transaction costs of the market. The increase of institutional change performance of economy provides efficiency.

The NIEH discusses within a new paradigm without rejecting optimality problem of mainstream economics. Whereas, Coase and North approaches deal with the set of context and analysis with the terminology that are not included in mainstream economics. Both approaches are close to heterodox economics because of the terminological and methodological similarities monitored in the process of analysis and understanding of economic reality and problem. Coase and North approaches work through the realism approach which is theoretically consistent, but at the same time critical against the perception of economically insignificant, abstract, hypothetical world. Preferring the critical realist methodology against real world problems is the rising point of both approaches.

In social sciences, in sociology and in economics literature of the OIE, institutions are stable cultural features of societies that shape the behavior surpassing the individual actors. On the contrast, from the evolutionary new institutionalists' point of view, institutions are behavioral traits, habits, preferences and norms. According to Prada, institutions show the similarities and differences in terms of transaction costs in market, the size of firm and state in OIE and NIE. Some circles of NIE criticize the protective belt of mainstream economics by using institutions under conditions of "bounded rationality/transaction costs". On the other hand, some circles make analyses that strengthen the protective belt of mainstream economics through "rational choice" and "game theory" models.

The context of the OIE is the evolutionary content of the economy. This content naturally refers to changing economic rules and institutions. However, the context of the NIE is the price mechanism to reduce transaction costs in the market economy. In the NIE, attention is drawn to evolutionary aspects of institutional change process by putting forward the institutions' reducing the transaction cost function in the market. The institutions such as firms, markets and property rights are defined in the contexts of transaction costs and effectiveness. The evolutionary processes that reduce transaction costs in the institutional market and beliefs / social representations rationalizing effectiveness are in the center of economic analysis (Orhan, 2016). 
Orhan, S.S. (2016), "In the New Institutional Economics Approach R. Coase and Law, D. North and Social Psychology Context: Pluralist Approach Opportunities in Economics", Sosyoekonomi, Vol. 24(28), 189-208.

In socio-economic life institutions are constraints determining the social cognitive $^{3}$ (Hodgson, 1993; 5). These constraints are reproducing themselves by providing information on their own. The institutional cognition is affecting and producing the individual economic behavior through informatics way, purposeful principles or perceptual processes. Institutions have strong motivation/teleological effects on individual goals. Harold Demsetz (1967), Andrew Scott (1981), Richard Langlois (1986), Jack Knight (1992), Daniel Kwita (2000) and D. North describes the institutions as the knowledge providing individual with data/information about the actions of others. In developed market economies, the transaction costs in the economy are reduced by settling informatics cognition in the community. Institutionalization process takes place at lower costs. There is an advanced informatics cognition level earned in the society under the rapid decline in the transaction costs.

In social behavior context, individual's informatics perception is decisive in the interpretation of the information through affecting the perception of reality. Preferences and choices that shape individual behavior are formed by level of the perceptual information ${ }^{4}$ (deeper cognitive function). Institution is the individual's informatics cognition, and it is the name given to the whole process. The individual cognition prominent in psychology leaves it place to social learning concept ${ }^{5}$ of social psychology. This concept better explains the

3 Social cognition: is our manner of remembering, analyzing and interpreting of information, and giving meaning through past experiences and cultural values to social world (people and me). (Baron \& Byrne, 1997). Cognitive theory works on effects and the topic of how man gets the information about the social world, how he perceives the social area and how he behaves in the social field on the basis of such information (Scheerer, 1954). Social psychology is cognitive. The causes of social behavior are also cognitive. In social psychology, from Kurt Lewin till today, social behavior has been considered to be more descriptive as a function of man's perceptions about social area. Social behavior cannot be taken as the objective descriptive function of the human about environmental stimuli (Zajonc, 1980 a). Social psychologists usually analyze not the only reasons of behaviors, but also they try to give analysis on the cognitive aspects, effects and the results of the whole social behavior. Social psychology is cognitive because it describes the cause and effect relationship of human behavior as a reasonable creature. (Fiske \& Taylor, 1984).

4 Perceptive cognition: there is a view on the basis of social cognition approach that the social perception (perception of man) is a cognitive process. According to this view, man is not a passive recipient. He is an effective organizer. He tends to organize all seen, heard, touched or the knowledge gained in different ways as consistent and meaningful wholes (perceptions and impressions) (Sears, Freedman and Peplau, 1989). Cognition topic is related to man's interpretation, analysis, use and the forms of remembrance of the information about a generic domain (other people). The basic fact of social cognition is that it is information installed.

5 Social learning: Rotter defines man as a conscious creature capable of affecting the life experiences which affects his life. Still, there are also external stimuli and reinforcements affecting human behavior. Personality represents the relationship between individual and his environment. It is necessary to consider both the individual (past learning and experience) as well as the environment (which is the individual aware of and react as stimulants) in order to understand human behavior. (Mearns, 2004; Korkmaz, 2003). With his social behaviorism approach A. Bandura is a pioneer of today's social learning process. Social learning theory aims at explaining the learning experience of a person. Thinking that imitation and observation prove insufficient in the process of learning, Bandura expands social learning theory by adding cognitive processes like thinking, memory, language and estimation and evaluation of the results of behaviors (Malone, 2002). Human is an active participant in the course of life. He is not a creature satisfied with just observing the mental mechanisms driven 
Orhan, S.S. (2016), "In the New Institutional Economics Approach R. Coase and Law, D. North and Social Psychology Context: Pluralist Approach Opportunities in Economics", Sosyoekonomi, Vol. 24(28), 189-208.

institutionalization process as seen in Knight and North's works in the NEIH approach. In economic life, the rules of law, culture, history, conditions/context, all formal/informal institutions are determinants of human cognition. In this approach, individual is analyzed without being isolated from "human mind" the legacy of the social process and without being detached from the social context in which he/she belongs. The content of the faith considered indispensable for humanity is determined by institutional rules (Knight, 1997). In the new institutional economics approach, perception bound cognition represents a deeper cognition.

In the NIE approach, holistic method fed from the context of social psychology is the preferred method rather than the methodological individualist relationship established between behavioral psychology and economics. In all economic systems, institutional structure is a place where the historical, cultural or ideological heritage of society is encoded in mental memory and the social schemes produced and transferred. North considers (1995, 5) that ideology is similar to the informal constraints of institutions. Ideology is part of the so-called cultural heritage. Culture defines the process of making use of knowledge by individual through preparing conceptual structure where the information is encrypted and interpreted. Individuals in social life, based on the informatic or perceptual consciousness level, are internalizing mental models with institutional structure while being articulated to this structure. As interpreting economic life, human mind shapes its perception of information through cognitive models it created.

Streit, Mummert and Kwita $(1997,688)$ state that cognitive models are the part of the socialization process of the individual. They are the carrier codes between generations. Cognitive models introduce us to the concept of ideology. In social life social representations ${ }^{6}$ are produced by orientalist effects consecrating authority figure. As to

by environmental events. Sensory, motor and systems related to the brain are the tools used to achieve the purposes directing and giving meaning to people's lives (Bandura, 1999). The attention is drawn to the distinction between the physical basis and functional aspects of thinking. Cognitive processes do not occur only in activities related to the brain, but also it is effective in the decision-making processes. The human mind is not only reactive (reactant), but it is in creative, proactive and self-reflective nature. Human is the producer of the idea that has decision-making functions. In order to adapt to changing situations human being plans his future actions, evaluates the functional aspects of the action, organizes strategically selected preferences and evaluates the possible consequences of his behaviors. (Bandura, 1999).

6 Social representations based on the experience of people, social representations are oriented on how people developed the theory and what they talk. These theories affect behaviors by recreating social reality. Social representations are generated, changed and spread during communication. They are expressed in oral and written traditional communication network. (Moscovici, 1984). Moscovici likens the emergence format of the social representation to an artist who divinizes the statue of his own creation, and who obeys and worships it. There is no undistorted information imposed by social representations. Social representations cover our religious beliefs, our political views, the contents of all our accumulation of thoughts and all our daily thoughts adapted the communication we have created. According to the approach of social representations, the prior step to understanding the social structure is the analysis of anonymous real (Moscovici, 1988). Per Moscovici social representations are phenomena that evolve over time as content, dissociated in the community and quickly 
Denzau and North (1994) ideology undertakes roles like the game rules (constraints) in interpretation of reality and understanding the institutions. Moving from social experience, culturally shared mental models facilitate generic communication by accelerating the learning process. Mental models pass cultural heritage, historical understanding and individual perception from generation to generation. Ideology is a decisive actor of individual in the process of perception and configuration of the outside world. In a sense, institutions in Denzau and the North's approach are the social learning processes.

In modern industrial society, behavior patterns giving direction to market relations are produced by the institutions. In the view of D. North in the NIEH approach, in institutionalized economies individual finds solutions with the help of institutions to all complex situations which he couldn't foresee due to missing knowledge kit. Davis and North (1971, 133) believe that continuity of market operations and the reduction of transaction costs depend on the institutional environment and institutional arrangement where the economic relations take place. In terms of the NIEH literature, institutional environment is an institutional structure. Individual and organizations which he is in are developing and changing institutional arrangements with a comprehensive set of rules (rules of the game).

In the OIE approach the institutional environment is the "behavioral constraints" which are in the background of the economic action. "The rules of the game" shape the individual behavior in competitive team game. (Davis and North, 1971). However, the institutional environment is discussed in a broader context in NIEH approach. Institutions in the market game are shaped by open formal rules such as behavioral constraints, constitutional order, and the rules of law and property rights and by implicit informal rules such as social traditions and norms. Veblen (1898), thinks that the process of institutional change is based on Darwinian views. Institutions stem from the nature of man being a social animal historically and culturally. (Parada, 2002). Veblen's starting point is William McDougall's (1908), "Introduction to Social Psychology" and J.B. Watson's "Behavioral Approach".

Institutionalism in the OIE context is not an analysis tool reducing operating costs as used in the NIE approach. According to all institutionalist approaches, by fighting what is there in social life human can reach an institutional structure achieved through the habits by passing through a process of selective adaptation. By this way, an evolutionist vision can be installed into institutions. In the OIE literature, institutions, traditions and customs are important in the determination of human behavior and behaviors are restricted by social institutions without neglecting the concept of rationality. Institutions in social life are common behavior patterns such as: individual actions that control collective actions; widely 
Orhan, S.S. (2016), "In the New Institutional Economics Approach R. Coase and Law, D. North and Social Psychology Context: Pluralist Approach Opportunities in Economics”, Sosyoekonomi, Vol. 24(28), 189-208.

considered opinions; social habits that have been standardized; (embeddedness) actions or ways of thinking settled in the habits of the group or in the tradition of an individual (Neale, 1994).

\section{NIE and Bounded Rationality}

In NIE, corresponding Williamson, North draws attention to cooperation and opportunistic behavior tendencies in certain institutional constraints. Institutional constraints such as property rights, land rent are immaterial in markets working with the full information and where ambiguity is perfectly measured. However, institutional structure reduces the economic performance in markets working with high transaction costs and where ambiguity cannot be measured due to limited information. Under conditions of limited information and bounded rationality, constraints reduce the costs of social networking system working between institutions and individuals (North, 1990: 34). Bounded rationality assumptions used in different contexts in the approaches of Coase, Williamson and North. While bounded rationality is discussed within the relationship of property rights and transaction costs in both Coase and Williamson's approaches, economy requires institutional changes due to bounded rationality in North's approach. Transaction costs will be reduced. In this way, development performance of an economy will increase.

In Coase's approach, actor's being rationally bounded ${ }^{7}$ will force economy and legal institutions into reciprocal relationship. All market relations create external benefits and costs. The dynamic change process that allocates property rights between the parties and re-defines the conditions of contract in relation to the problems arisen from market, only be resolved in the reciprocal relationship of economics and law. Coase (1977) regards the assumption that man is a rational utility maximizer to be both unnecessary and misleading in terms of the preferred (benefit/profit) of neo-classical economics. According to the literature of modern institutional economics, man live in the market order which is confined by economic life institutions. The boundaries of the market order are determined by the laws.

Unlike Coase, North defines institutional change process in the size of firms and markets. Next to Coase, O. Williamson is the second prominent representative of the NIEA in the contexts of bounded rationality, property rights and transaction costs. He defines the development process by emphasizing the concept of bounded rationality in his transaction costs approach. The term NIE was first used by O. Williamson (1975) in his "Markets and Hierarchies" book and was quickly acknowledged in the economics literature. In transaction

7 Simon, H. (1965), “A Behavioral Model of Rational Choice”, Quarterly Journal of Economics, 69, 99-118. Simon, H.A. (1987), “Bounded Rationality”, In: J. Eatwell, M. Milgate, and P. Newman, eds., The New Palgrave: A Dictionary of Economics, 1:266-68, London: Macmillan. 
cost approach (TC) social norms, traditions and trends are accepted as data, while institutional change is watched rather slowly.

Granovetter (1985) argued that Williamson's market and hierarchy dichotomy means a return to a Hobbesian approach by pointing out the relationship formed between the authority and concept of opportunistic behavior. Williamson ignores the dimension of individualistic behavior trends in personal relationships. The NIEH and TC approaches differ from each other regarding the assumptions of economic behavior. According to $\mathrm{O}$. Williamson, the parties in response to trading freely in the market, with concerns for the future they enter the opportunistic behavior trend under conditions of uncertainty where the costs of acquiring information are higher in monopolistic markets.

The existing contracts in these types of markets are not complete and perfect. Monopolistic conditions arise between the parties after the contract in response to having freedom to negotiate with whoever they want before making a contract. Knight type of contract is impossible which covers all possible behavior trends. However, it is possible to limit the developing trend of opportunistic behavior between parties in market relations where the principles of contract is institutionalized. On flexible contracts, opportunistic behavior trend is limited by legal and personal regulations in accordance with governance structure. O. Williamson claims that because of bounded rationality, institutionalization reduces rising transaction costs in competitive markets. However, institutional change is a very slow functioning process. Whereas, according to North, in the face of bounded rationality institutionalization process increases efficiency in the economy by lowering transaction costs. It is important for institutional change and development relationship to be in nature to provide efficiency. Institutional structure of the society changes as a whole by informal and formal rules in North's approach.

The relationship between economics and social psychology, formed from the context of institutions in North's approach, is different from Coase and Williamson's approaches. D. North (1995: 18) discusses the transaction costs reducing function of institutions in the context of "institutional rationality" concept. Institutional development is a key performance indicator in terms of history of economics. Accordingly, economic and political decision-making processes are inseparable. These processes are reflected in the public decision in the political operations. The purpose is to prepare a theoretical frame explaining institutional change. Ideology, understanding, cognitive and moral belief system gain importance in economic relations. Continuity is essential in social life (North, 1978: 972).

North adds a universal holistic theoretical content to the problem of politics and economics via bounded rationality concept. In this way, it transfers political economy debates into economics literature. Unlike the Public Choice and Collective Action Theory, the process of rational choice and Efficient Market Hypothesis are criticized through bounded rationality and the ideological principles. In North's approach, mental models, 
Orhan, S.S. (2016), "In the New Institutional Economics Approach R. Coase and Law, D. North and Social

Psychology Context: Pluralist Approach Opportunities in Economics”, Sosyoekonomi, Vol. 24(28), 189-208.

relationship between ideology and institutions become analytic concepts in the interpretation of the reasons of human existence and in the regulation of the environment.

In Williamson's approach, institutionalization is a condition that reduces transaction costs. However, according to D. North, it is important to ensure the efficiency in market relations, while lowering transaction costs by institutions. However, in North's approach, the context of institutional rationality charged on individuals and markets through institutionalization would be subject to criticism in some circles which are targets of institutional efficiency. Since, Pareto efficiency is not a significant case in the institutional economics approach. In institutional operations, the cause of the deterioration of efficiency is the operation of the decision-making mechanisms outside of the effectiveness requirements in political markets (Furubotn \& Richter, 2005: 108-110).

Richter (2005) believes that NIEH and TC differ from each other in the context of full and bounded rationality. In Williamson's line TC works within the method of "partial institutional analysis". However, North emphasizes "total institutional analysis" method in NIEH approach. Either way, under bounded rationality conditions market economy works with high transaction costs. There are some important differences against some circles who consider it similar to the demand-supply mechanism in Walrasian general equilibrium analysis. In the TC approach, institutionalization discussions are held over price theory through methodological individualist approach and microeconomics such as firm theory, antitrust theory and industrial organization economics. However, the NIEH approach analyzes the institutional performance of economics through the context of mental models and social representations in historical perspective. Therefore, transition economies and development economics requires a holistic approach in the context of institutional performance and history of economics.

\section{Conclusion}

In this study, the relation between the OIE - one of the radical approaches of the heterodox economics and the NIE - a part of mainstream economics is analyzed. In this way, the emphasis is on the main contrasting points of both approaches to mainstream economics. Despite theoretical and methodological differences between them, both the OIE and the NIE approaches demonstrate continuity through ontological point of view towards the concept of institution. Due to the continuity relationship, the NIE plays a carrier role in transferring certain heterodox terms to mainstream economics. The institutional terminology which has been brought into by the NIE is internalized in rationality and efficiency assumptions of mainstream economics. In a sense, there is a chance for price mechanism to be discussed together with the social context that has been ignored in the market relations.

Coase argues that $(1937,1988)$ the institutionalization of market to the size of the firm provides optimal resource allocation by reducing the transaction costs of price mechanism. In a sense, Coase is a strong link between economics and law. Coase's analysis of property rights discusses the boundaries of all benefits and costs caused by organizations 
of firm scale in different sectors. Law and economics relationship established by Coase's context of transaction costs and property rights is further expanded in the framework of economics, management sciences and political science in North's context of institutional development performance. In this respect North stands at the crossroads between economics and social psychology, anthropology and political science. The institutional terminology which has been brought into by the NIE is internalized in rationality and efficiency assumptions of mainstream economics. In a sense, there will be a chance for price mechanism to be discussed together with the social context that has been ignored in the market relations.

R. Coase states in the New Institutional Economics that the price mechanism which reduces transaction costs creates a legal environment that enables the optimization of resource allocation in a firm based institutionalized market economy. R. Coase is the most powerful and simple connection between economics and law. On the other hand, D. North in the New Institutional Economic analyses the institutions social cognition accepted theory in social psychology. In this way, D. North, social cognition, mental models, social representations and social learning such as the analysis of sets used in social psychology makes economic analysis. Consequently, the economy gets away from the influence of behavioural psychology; it captures the convergence opportunity in the social context. The institutional economics, which emphasizes the ontological context of continuity of the institutions, strengthens the pluralist methodology in economics.

The NIE terms such as "behaviors and attitudes", "social cognition" "group dynamics", "public decision-making processes", "the problem of governance," "hegemonic power relations", "government and pressure groups" are the social context that were emerged from man's relationship with the other man, being a part of social life and relationship with the government. The social context of economics is bringing it close to social psychology, political science and law. The mainstream theory gets two important developments through institutional terminology. The first, economics gains a pluralist methodological perspective as long as the social context of economics explaining economic behavior has been transferred to economics. The second, economics will have a chance to produce mainstream theory's ideas and economic policy of its own by approaching the social context which has lost.

\section{References}

Bandura, A. (1999), "Moral Disengagement in the Perpetration of Inhumanities", Personality and Social Psychology Review, (Special Issue on Evil and Violence), 3, 193-209.

Baron, R.A. \& D. Byrne (1987), Social Psychology: Understanding Human Interaction, New York: (5th. Ed.), Boston: Allyn \& Bacon.

Commons, J. (1990 - 1934), Institutional Economics: Its Place in Political Economy, New Brunswick, New Jersey, Transaction Publishers Vols. 1-2.

Coase, R.H. (1960), “The Problem of Social Cost”, Journal of Law and Economics, 3, 1-44. 
Coase, R.H. (1977), "Economics and Contiguous Disciplines", in: The Organization and Retrieval of Economic Knowledge, Ed., Mark Perlman.

Coase, R.H. (1988), The Firm, The Market and The Law, Chicago: University of Chicago Press, 1988.

Coase R.H. (1992), "The Institutional Structure of Production”, The American Economic Review, Vol. 82, No. 4. 713-719.

Coase, R.H. (1937), “The Nature of the Firm”, Economica, New Series, 4(16), 386-405.

Davis. L.E. \& D.C. North (1971), Institutional Change and American Economic Growth, Chambridge, Chambridge University Press.

Denzau, A. \& D.C. North (1994), "Shared Mental Models: Ideologies and Institutions", Kyklos, 47, 3-31.

Furubotn, E.G. \& R. Richter (2005), Institutions and Economic Theory: An Introduction to and Assessment of the New Institutional Economics, 2nd ed. Ann Arbor, Mich.: University of Michigan Press.

Galbraith, J.K. (1967), The New Industrial State, Boston: Houghton Mifflin.

Granovetter, M.S. (1985), "Economic Action and Social Structure: The Problem of Embeddedness", Am. J. Soc., 91, 481-510.

Gruchy, A. (1947), Modern Economic Thought: The American Contribution, New York: PrenticeHall.

Korkmaz, İ. (2003), Sosyal Öğrenme Kuramı, Gelişim ve Öğrenme Psikolojisi, Ed. B. Yeşilyaprak, Ankara: Pegema Yayıncılik.

Langlois, R.H. (1986), “The New Institutional Economics: An Introductory Essay”, Kapitel 1, ed. R.H. Langlois, in: Economics as a Process, Essays in the New Institutional Economics, New York.

Malone, Y. (2002), "Social Cognitive Theory and Choice Theory: A Compatibility Analysis", International Journal of Reality Therapy, 22 (1), 10-13.

McDougall, W. (1908), An Introduction to Social Psychlogy, London: Methuen.

Mearns, J. (2004), The Social Learning Theory of Julian B. Rotters, <http:/psych. fullerton.edu/jmearns/rotter.htm>, 12 Mayıs 2015.

Moscovici, S. (1984), “The Phenomenon of Social Representations”, in: Social Representations, R.M. Farr \& S. Moscovici (Eds.), Cambridge: Cambridge Press.

Moscovici, S. (1988), "Notes Towards A Description of Social Representations”, European Journal of Social Psychology, 18, 211-250.

Hodgson, G.M. (1998), “The Approach of Institutional Economics”, Journal of Economic Literature, $36,166-192$.

Knight, J. (1997) “Social Institutions and Human Cognition”, Journal of Institutional and Theoretical Economics, 153(4): 693-99.

North, D.C. (1978), "Structure and Performance: The Task of Economic History", Journal of Economic Literature, 16, 963-978.

North, D.C. (1990), Institutions, Institutional Change and Economic Performance, Cambridge: Cambridge University Press, pp.VIII, 152. ISBN, 0521 394163, 0521397340.

North, D.C. (1995), The New Institutional Economics and Third World Development, in: Harriss, Hunter and Lewis (1995a), 17-26. 
Orhan, S.S. (2016), Türkiye'de Kuramsal Olarak İktisadi Düşünce: İktisat Kurumunun Modernist Sosyal Bilişi, Otoriter Sosyal Temsiller ve Liberal Retorik, E. Yücelkaya (Ed.), İletişim Yay. Basım Aşaması.

Parada, J. (2001), “Original Institution Economics: A Theory for 21st. Century”, Oeconomicus, Vol. 5, Fall 2001, 46-60.

Parada, J. (2002), “Original Institutional Economics and New Institutional Economics: Revisiting the Bridges (Or the Divide)", Oeconomicus, Volume VI, Fall 2002.

Richter, R. (2005), “The New Institutional Economics - Its Start, Its Meaning, Its Prospects 1”, Revised 9 November, 2005, An earlier version appeared in: The European Business Organization Law Review (EBOR), 6:2, 161- 200.

Rutherford, M. (1994), The Old and The New Institutionalism, Cambridge: Cambridge University Press.

Rutherford, M. (1995), “The Old and The New Institutionalism: Can Bridges Be Built?", Journal of Economic Issues, 29, 443-451.

Scheerer, M. (1954), “Cognitive Teory”, G. Lindzey (Ed.), in: Handbook of Scoial Psychology, Vol. 1., Cambridge, Addison-Wesle.

Sears, D.O. \& J.L. Freedman \& L.A. Peplau (1989), Social Psychology, Englewood Cliffs, N.J., Prentice Hall, Inc.

Simon, H. (1965), “A Behavioral Model of Rational Choice”, Quarterly Journal of Economics, 69, 99-118.

Simon, H.A. (1987), "Bounded Rationality”, J. Eatwell, M. Milgate and P. Newman, (eds.), in: The New Palgrave: A Dictionary of Economics, 1:266-68, London: Macmillan.

Williamson, O.E. (1975), Markets and Hierarchies: Analysis and Antitrust Implications, NY: Free Press. 